\title{
Examination of Routine Activities Theory by the property crime
}

\author{
Uğur Argun ${ }^{1}$ \\ Murat Dağlar ${ }^{2}$
}

\begin{abstract}
The studies on crime prevention, causes of crime and the theories associated with it are very essential topics in criminology. Routine Activities Theory (RAT) is also the basis for the many criminological theories. Although it has some shortcomings it is very usual that the theorists and practitioners on crime prevention can benefit from such a strong theory. This study explains the applicability of Routine Activities Theory in prevention and reducing of property crimes in the context of some parameters related to burglary and auto theft incidents in US. The study aims to give some information of the routine activity theory and investigate its relationship with prevention of property crimes. The results of study suggest that Routine Activity Theory may be used as a useful tool by crime reduction or prevention practitioners to evaluate crime problems and also take routine precautions and measures that reduce crime opportunities in people's daily activities.
\end{abstract}

Keywords: crime prevention, routine activities theory, property crime, burglary, auto theft

\section{1-Introduction}

There are many criminological theories that endeavor to explain how and why crimes take place such as rational choice theory (Cornish and Clarke 1987; Dolu 2009a; Dolu 2009b), situational crime prevention (Clarke, 1997; Pease 1992; Poyner 1997), routine activity theory (Cohen and Felson 1979; Felson and Clarke 1998). Routine activities approach is a theory which presents a clear-cut explanation of why crimes occur. Namely, this theory tries to clarify why crime occurs under some specific circumstances rather than understanding criminal characteristics as temporal displacement (Felson and Clarke 1998:25), characteristics of offenders (Buikhuisen et al 1984:301) and etc. In the past, it was applied to direct-contact predatory and property crimes; nowadays it can be applicable to many other kinds of deviant behaviors.

At the beginning routine activities theory was used to explain changes in crime trends over time. It has been progressively used much more generally to determine, define and prevent crime problems. Researchers have used versatile methods to test hypotheses derived from the theory. Since its inception, the theory has become closely aligned with a set of theories and perspectives known as environmental criminology, which focuses on the importance of opportunity in determining the distribution of crime across time and space. The routine activities theory in particular has very practical implications for prevention; therefore, practitioners have applied routine activities theory to inform police practices and prevention strategies.

\footnotetext{
${ }^{1}$ Ph.D., Ankara Police Department, u argun@hotmail.com

${ }_{2}^{2}$ Ph.D., Nigde Police Department, muratdaglar1974@yahoo.com
} 
This study explains the routine activity theory by implementing it to some property crimes. The study starts with succinct information of the routine activity theory and summary of property crimes, specifically burglary and motor vehicle theft. Then, it will be tried to find out how the routine activity theory is applicable to the property crimes in the context of some parameters related to burglary and auto theft incidents in USA. Lastly, a conclusion section will be rendered that summarizes this study in brief.

\section{2-The Scope of the Routine Activity Theory}

The routine activity approach was presented by criminologists Lawrence Cohen and Marcus Felson in 1979. Cohen and Felson believed that crime occurs in the presence of three elements which are a suitable target, lack of a suitable guardian, and a likely motivated offender (1979:589). Namely, a crime happens when these three elements intersect at any point in time. Routine activity theory suggests that if all three elements- a suitable target, lack of a suitable guardian, and a likely motivated offender- are available somewhere, then the chances for crime increase and conversely, if one of these elements is absent then chances for crime decrease.

Specifically, Cohen and Felson believe that "guardianship by ordinary citizens of one another and of property as they go about routine activities may be one of the most neglected elements in sociological research on crime, especially since it links seemingly unrelated social roles and relationships to the occurrence or absence of illegal acts." (Cohen ad Felson 1979:589). According to Cohen and Felson, the number of people, acting as guardians, who are at a residence for a long portion of the day has decreased due to increasing participation of women in the work force in daily life. Homes are often left unguarded while both mothers and fathers are at work and children are at school for education. Also, the expansion of suburban living and the vanishing rate of conventional neighborhoods have reduced the number of familiar guardians, such as neighbors, family, or friends. Consequently, by expression of "routine activities," Cohen and Felson mean that during daily and ordinary activities of life, individuals put themselves in situations which raise or decline their risk of being criminally victimized (Degarmo 2011:585-586).

Especially to conceive the situational aspects of crime, the theory of routine activities offers to get together time and space as an imperative function of criminal understanding of places of crime. The emphasis on situational aspects, particularly of space, makes crime a built in feature of our social organization (Degarmo 2011:585).

The people we interact with, the places we travel to, and the activities we engage in influence the likelihood and distribution of criminal behavior. The presence of a motivated offender, a suitable target, and a lack of guardianship does not mean that crime is inevitable. Instead, the theory argues that the likelihood of crime increases or decreases based on the existence of these three elements.

In summary scope of this theory -related to property crime- depends on a trivet. First, victimization risks increase where the levels of visibility and accessibility of target increase. Second, where the levels of self-protection or guardianship enabled high, individuals' risks and high rates of predatory crime can be diminished. Third, less attractive targets have lower risks of victimization to offenders than persons and property with higher subjective or material value (Brunet 2002:69).

\section{3-The Elements of Routine Activity Theory}

According to routine activity theory, a crime picture is painted by three elements, so to say. The first one is a suitable target.

\section{A Suitable Target}

Anything can be a target such as a person, an object or a place which can be attractive and fruitful for criminals. An object may be very attractive when it is visible and its value is high and easy to reach. In other words, a suitable target is something which provides instant profit to offenders. This might be a woman walking home alone at night, an overpass just begging to be tagged by a gang, or a purse or wallet left on a chair in a restaurant as its owner leaves to use the 
Argun, U., \& Dağlar, M. (2016). Examination of Routine Activities Theory by the property crime. International Journal of Human Sciences, 13(1), 1188-1198. doi:10.14687/ijhs.v13i1.3665

bathroom. The target is an easy one, one that would not be difficult for the motivated offender to approach (NSW Attorney General 2011). Offenders generally choose to commit crime simply upon meeting an opportunity, rather than engaging in intensive planning. So, it can be said that suitability of target is essential.

\section{Absence of the proficient Guardian}

The second element is proficient guardian absence. Guardianship is defined as the physical or symbolic presence of an individual (or group of individuals) that acts (either intentionally or unintentionally) to deter a potential criminal event (Hollis-Peel et al. 2011:4). The proficient guardian, whose presence would discourage a criminal from committing a crime, can be a person or a thing such as a friend, police, lighting, locks or an alarm system. Yet, the presence of a guardian cannot be enough to prevent an offender when the guardian is not effective. For example, we cannot say a juvenile is a guardian for a mother in the darkness of the night on a quiet street because the juvenile may not be considered as an effective guardian in such a situation for many criminals.

Guardianship can be defined at individual and environmental levels and can be drawed on recent multicontextual criminal opportunity theory for specific definitions at each level. At the individual level, guardianship is defined as "possessing qualities that relate to social ties and interpersonal control," with interpersonal control referring to "the degree to which individuals and objects in a bounded locale can be observed and impeded from experiencing criminal acts because they are proximate and exposed to agents of formal control, agents of informal control, and nonhuman protection devices" (Wilcox, Land and Hunt 2003:62). Environmental-level guardianships "the collective degree to which individuals or objects in a bounded locale possesses qualities related to social ties and social control," with social control encompassing, again, informal, formal, and nonhuman security (Wilcox, Land and Hunt 2003:64).

\section{Possible offender}

The last element is the likely offender. When an appropriate target is undefended by a proficient guardian there is a chance that a crime will take place. Consequently, the final component in this picture is that a likely offender has to be present for commission of crime.

In other words, once a potential offender seizes the correct target without any guardians present as well as at the most appropriate time and place, he/she will commit a crime. The theory states further that the absence of either one of these three elements will be sufficient enough to hinder the occurrence of successful criminal actions. Furthermore, Cohen and Felson (1979) argued that changes in social structures and economies of the modern world allow an increase in possible opportunities for motivated offenders to commit crimes of different forms.

In summary, according to routine activity theory, crime can only be committed if a likely offender thinks that a target is suitable and a capable guardian is absent. Daily and ordinary activities of life can put people in a situation which makes them easy victim of crime.

\section{4- Strengths and weaknesses of the RAT \\ Strengths}

The routine activities approach has mainly seen empirical support in the area of exposure of victims to offenders. A number of strengths are included as below;

First of all, "Routine Activity Theory" provides a simple and powerful insight into the causes of crime problems. At its heart is the idea that in the absence of effective controls, offenders will prey upon attractive targets.

Another significant contribution is also adding a time dimension to crime-space relationship that is not explored previously in the criminology literature (Dolu 2010:121). As illegal activities must feed upon other activities, the spatial and temporal structure of routine activities should play an important role in determining the location, type and quantity of illegal acts. This is an ecological approach by which theorists attempt to show how people interact within a given environment. 
Argun, U., \& Dağlar, M. (2016). Examination of Routine Activities Theory by the property crime. International Journal of Human Sciences, 13(1), 1188-1198. doi:10.14687/ijhs.v13i1.3665

According to the theory crime rates are not affected only by absolute size of the supply of offenders, targets, or guardianship but also, the factors affecting the frequency of their convergence in space and time (Sherman, Gartin and Buerger 1989:31).

On the other hand "the chemistry of crime can be reduced to the interaction of three vital elements- a likely offender, a suitable target, and the absence of a capable guardian against the offense. The ways in which these elements are made to coincide in time and space are a function of our social arrangements and everyday routines. This chemistry has been mainly measured in the area of hot-spot policing, which is the use of proactive policing tactics and general police saturation to reduce crime in the $3 \%$ of urban areas which contribute around $50 \%$ of a cities total crime rate" (Degarmo 2011:585).

The routine activities approach has become a stock ingredient in many popular theoretical integrations and the explanatory power of routine activities theory has been extended beyond predatory crimes to other types of illicit activities such as juvenile delinquency, fights, and various forms of vice (Brunet 2002:71).

The hallmark of the theory is its de-emphasis upon the offender and shift of attention towards the target and guardian. This target can be any person or property that any offender would like to take or control, the term target is used rather than victim because it emphasizes the physical nature of each criminal act (Felson 2001).

Routine activities approaches hold some interesting opportunities for crime mapping and analysis and can help guide strategies for crime control and resource deployment. The inclusion of contextual variables that measure various aspects of routine activities may improve the prediction power of crime maps and analyses, increasing their usefelness.

\section{Weaknesses}

A number of weaknesses are included as below;

While routine activities theory provides valuable contributions to the study of space and crime, scholars critique the theory on a number of grounds. For example, while routine activities theory assumes the presence of motivated offenders, many researchers discuss how motivations vary across offenders (Clarke and Cornish 1985). Others argue that routine activities theory fails to properly address the role of criminal opportunity contexts - the circumstances in which motivated offenders and suitable targets converge in the absence of capable guardians (Wilcox, Land and Hunt 2003).

Brunet (2002:75-76) depicts the weaknesses of RAT on several criticisms: The first criticism centers on the issue of crime displacement. This is an enduring criticism of routine activities theory. Some argue that the discouragement of a criminal event today does nothing to reduce the likelihood that a similar crime will be committed by the offender at another time and place. As the argument goes, guardianship simply moves crime from one area to another area.

Second, routine activities theory tends to ignore the research literature that associates crime with offender characteristics (social learning, psychological, identity, self-esteem). The latest iterations of the theory have corrected this, in part, by moving toward a more complex and realistic conceptualization of the likely offender.

Third, there is a heated debate within the routine activities camp over the proper conceptualization of the theory as a micro or macro approach to crime.

Fourth, most studies which test the theory are post hoc and descriptive. At this stage in its development, the theory is limited in its predictive capacity.

According to another theorist, Degarmo (2011), the routine activities approach is plagued with theoretical discrepancies and he tried to combine routine activities with a theory of contagion may allay some of theoretical issues. But these theories are essentially distinguished from one another by what each omits from the other. The routine activities approach places emphasis on the confluence of crime while the contagion perspective focuses on transmission of crime. Confluence refers to the coming together of offender and victim in a suitable crime location and specific time. Contagion, however, looks more at how an emotion, particularly aggression, spreads from person 
Argun, U., \& Dağlar, M. (2016). Examination of Routine Activities Theory by the property crime. International Journal of Human Sciences, 13(1), 1188-1198. doi:10.14687/ijhs.v13i1.3665

to person regardless of location or time (Degarmo 2011:593). Thus, routine activities theory merely assesses one crime or crime density in a location instead of looking at a string of inter-correlated crimes.

Routine activity theory has so far relied mainly on simple assumptions about the situations in which crimes occur (at night, at the hands of strangers). Second, with few exceptions research on situations has dealt only with cross-sectional data; the situational data now available from victimization surveys are inadequate to assess exposure (Degarmo 2011:586).

On the other hand, patterns of movement and activity or in other words routines of humankind have changed dramatically in the last decades. For example, many households today require two incomes. Having both guardians and also neighbors removed from the home every day, significantly reduces the offender's risk of getting caught during a daytime burglary.

Situated within the broader framework of environmental criminology, routine activities theory suggests that reducing criminal opportunities serves a key role in reducing the prevalence of crime.

In the theory some aspects of crime nature and components were incompetent and then factors of "intimate handlers", "place management", "responsibility levels for crime discouragement" and "crime facilitator" has been implemented (Brunet 2002:72).

\section{4-Examination of RAT through Property Crime Types}

In this part a number of property crime types and related figures will be examined regarding with routine activity approach.

\section{Burglary Cases}

Generally, burglary is explained as an act by anyone who has a specific intent to steal any property from others. Burglary is defined in the Uniform Crime Reporting (UCR) Program as the unlawful entry of a structure to commit a felony or theft (FBI Uniform Crime Report 2004:45). Burglary is a crime that normally is not violent because it does not pose a serious life-threatening situation. However, the victim may suffer from big economic loss depending on what was stolen from them. In addition to this, even if the monetary importance of stolen goods is not much, burglary may cause negative psychological effects for some time. Prenzler and Townsley (1998:297) notes that even where the monetary value of stolen goods is low, burglary often produces severe psychological effects. Especially insomnia, depression, and insecurity are common symptoms of the property crime's victims and generally women report longer term anxiety.

According to Cohen and Felson, many countries experienced a considerable rise in crime, including burglary, in the 1960s and 1970s with rapid economic development, the availability of easily stolen products and the movement of social life out of the home (1979:588). Like many other countries, in the United States burglary has been one of the most common crimes which increased quickly during the 1960s up to the mid-1980s (Prenzler and Townsley 1998:295). After this period there was a decreasing (1995-2000) and short rising trend in burglary and burglary rates. Comparing the burglary crime figures and rates in 2000 and 2004 it can be said that there was a rising period ( +4.5 in burglary crime and +0.2 in burglary rate).

In 2004, an estimated 2.1 million burglary offenses were committed in the United States. This figure (approximately 2,143,456) is a 0.5-percent decline from the 2003 estimate. An examination of 5- and 10-year trends demonstrated a 4.5-percent increase in the number of burglaries when compared with the 2000 estimate, and a 17.4-percent decrease from the 1995 number. Calculated at 729.9 burglaries per 100,000 people, the 2004 rate was a decrease of 1.5 percent from the 2003 rate. Although the 2004 burglary rate was slightly higher ( 0.2 percent) than the 2000 rate, it was 26.0 percent lower than the 1995 rate (FBI 2004).

But in last decades there was a decrease period in burglary rate (see table 1). In 2012, there were an estimated 2,103,787 burglaries, a decrease of 3.7 percent when compared with 2011 data. The number of burglaries was down 2.4 percent when compared with the 2003 estimate (FBI 2012). The overall property crime rate (which includes household burglary, theft, and motor vehicle 
Argun, U., \& Dağlar, M. (2016). Examination of Routine Activities Theory by the property crime. International Journal of Human Sciences, 13(1), 1188-1198. doi:10.14687/ijhs.v13i1.3665

theft) decreased from 131.4 victimizations per 1,000 households in 2013 to 118.1 victimizations per 1,000 in 2014. The decline in theft accounted for the majority of the decrease in property crime (FBI 2012). Despite the property crime increased directly proportional to population between 2002 and 2012 property crime rate and burglary rate decreased.

Table 1. Property crime rate per 100,000 population in USA

\begin{tabular}{|l|l|l|l|l|l|}
\hline Year & Population & $\begin{array}{l}\text { Property } \\
\text { crime }\end{array}$ & $\begin{array}{l}\text { Property } \\
\text { crime rate }\end{array}$ & Burglary & Burglary rate \\
\hline $\mathbf{2 0 0 2}$ & $287,973,924$ & $10,455,277$ & $3,630.6$ & $2,151,252$ & 747 \\
\hline $\mathbf{2 0 0 3}$ & $290,788,976$ & $10,442,862$ & $3,591.2$ & $2,154,834$ & 741 \\
\hline $\mathbf{2 0 0 4}$ & $293,656,842$ & $10,319,386$ & $3,514.1$ & $2,144,446$ & 730,3 \\
\hline $\mathbf{2 0 0 5}$ & $296,507,061$ & $10,174,754$ & $3,431.5$ & $2,155,448$ & 726,9 \\
\hline $\mathbf{2 0 0 6}$ & $299,398,484$ & $10,019,601$ & $3,346.6$ & $2,194,993$ & 733,1 \\
\hline $\mathbf{2 0 0 7}$ & $301,621,157$ & $9,882,212$ & $3,276.4$ & $2,190,198$ & 726,1 \\
\hline $\mathbf{2 0 0 8}$ & $304,059,724$ & $9,774,152$ & $3,214.6$ & $2,228,887$ & 733 \\
\hline $\mathbf{2 0 0 9}$ & $307,006,550$ & $9,337,060$ & $3,041.3$ & $2,203,313$ & 717,7 \\
\hline $\mathbf{2 0 1 0}$ & $309,330,219$ & $9,112,625$ & $2,945.9$ & $2,168,459$ & 701 \\
\hline $\mathbf{2 0 1 1}$ & $311,587,816$ & $9,052,743$ & $2,905.4$ & $2,185,140$ & 701,3 \\
\hline $\mathbf{2 0 1 2}$ & $313,914,040$ & $8,975,438$ & $2,859.2$ & $2,103,787$ & 670,2 \\
\hline
\end{tabular}

(Source: Federal Bureau of Investigation, Crime in the United States 2012.W ashington, DC: United States Government Printing Office.)

In house burglaries, the most commonly stolen objects were jewelry and cash, followed by video-players, hi-fis, tools, CDs, tapes, watches and TVs in the 1990s (Bridgeman and TaylorBrowne 1996:1). In the last decade the most commonly stolen objects were locally stolen motor vehicles, miscellaneous, jewelry and precious metals and currency, notes, etc. (see table 2). So, it can be said that offenders generally focus on portable properties which have monetary importance.

Table 2. Property Stolen and Recovered by Type and Value, 2012

\begin{tabular}{|c|c|c|c|}
\hline \multirow{2}{*}{ Type of property } & \multicolumn{2}{|c|}{ Value of property } & \multirow{2}{*}{$\begin{array}{l}\text { Percent } \\
\text { recovered }\end{array}$} \\
\hline & Stolen & Recovered & \\
\hline Total & $\$ 13.018 .440 .484$ & $\$ 2.672 .518 .711$ & 20,5 \\
\hline Currency, notes, etc. & 1.114 .798 .222 & 29.970 .580 & 2,7 \\
\hline Jewelry and precious metals & 1.884 .197 .755 & 76.079 .980 & 4,0 \\
\hline Clothing and furs & 283.544 .521 & 35.231 .828 & 12,4 \\
\hline Locally stolen motor vehicles & 3.837 .736 .642 & 2.068.239.691 & 53,9 \\
\hline Office equipment & 687.150 .488 & 38.934 .127 & 5,7 \\
\hline Televisions, radios, stereos, etc. & 756.448 .834 & 35.320 .311 & 4,7 \\
\hline Firearms & 139.015.479 & 12.939 .361 & 9,3 \\
\hline Household goods & 341.701 .901 & 12.220 .451 & 3,6 \\
\hline Consumable goods & 126.411 .259 & 15.010 .704 & 11,9 \\
\hline Livestock & 15.628 .200 & 1.245 .493 & 8,0 \\
\hline Miscellaneous & 3.831 .807 .183 & 347.326 .185 & 9,1 \\
\hline
\end{tabular}

(Source: Federal Burean of Investigation, Crime in the United States 2012.W ashington, DC: United States Government Printing Office.)

Unlike most mainstream criminological theories which look at offenders, routine activities theory (RAT) attempts to explain why crime is more likely to affect certain people and occur in certain situations. But as in a study (Sherman, Gartin and Buerger 1989:47) it is indicated ironically 
Argun, U., \& Dağlar, M. (2016). Examination of Routine Activities Theory by the property crime. International Journal of Human Sciences, 13(1), 1188-1198. doi:10.14687/ijhs.v13i1.3665

that focusing on the routine activities of places rather than of individual life-styles produces a different conclusion: Successful efforts to make targets less suitable, get guardianships increased and ensure the supply of potential offenders reduced, might produce net reductions in crime.

The causes of burglary and solutions to the problem are complex. Improved guardianship using a range of measures to deter offenders can be of some benefit, but with other aspect of theory by using "suitable target" as a core stand point preventing property crime can be more easy. Because at least when the targets made less suitable, for example by putting it an unseen position the property crime can be prevented. So, by changing the routines of life just as forgive the behavior of saving jewelry and cash in bedroom or putting cellphone on accessible places burglary or theft case can be prevented on micro level at the beginning.

RAT assumed that motivated offenders are present and focuses instead on suitable targets and guardianship measures. Because of this focus, routine activities theory is well suited for use on preventing the property crime.

\section{Motor vehicle theft}

One of the other property crimes is motor vehicle theft which is defined in Bureau of Justice Statistics official website (US Department of Justice, 2014) as stealing or unauthorized taking of a motor vehicle, including attempted thefts.. When the motor vehicle theft is scrutinized, it seems like a major problem of the community.

In the United States, there were an estimated 721,053 thefts of motor vehicles nationwide in 2012. The estimated rate of motor vehicle thefts was 229.6 per 100,000 inhabitants (see table 3). The estimated number of motor vehicle thefts declined 3.3 percent when compared with data from 2010, 35.0 percent when compared with 2007 figures, and 42.6 percent when compared with 2002 figures (FBI 2012).

The auto theft is a common crime in many modern societies. If one considers committing this crime, targets are widely available, have a variety of strong temptations to thieves, are afforded little guardianship by their owners, and they seem comparatively easy to enter and steal (Clarke and Harris, 1992). This approach is important because it recognizes the significance of time as well as place. An opportunity for auto theft may not exist at the location of a desirable car if the owner is in the driver's seat. However, a few minutes later, the owner may be on the twentieth floor of an office complex, making the car an excellent target of theft. On the other hand, if the car is parked in an attended lot or one equipped with surveillance cameras, it will not be a good target for theft. Both time and guardianship are important concepts in the routine activity approach to crime.

Table 3. National Statistics of Property Crime in USA

\begin{tabular}{|l|l|l|l|l|}
\hline Year & Population & $\begin{array}{l}\text { Property crime } \\
\text { total }\end{array}$ & $\begin{array}{l}\text { Motor vehicle } \\
\text { theft }\end{array}$ & $\begin{array}{l}\text { Motor vehicle } \\
\text { theft rate }\end{array}$ \\
\hline $\mathbf{2 0 0 2}$ & $287,973,924$ & $10,455,277$ & $1,246,646$ & 432,9 \\
\hline $\mathbf{2 0 0 3}$ & $290,788,976$ & $10,442,862$ & $1,261,226$ & 433,7 \\
\hline $\mathbf{2 0 0 4}$ & $293,656,842$ & $10,319,386$ & $1,237,851$ & 421,5 \\
\hline $\mathbf{2 0 0 5}$ & $296,507,061$ & $10,174,754$ & $1,235,859$ & 416,8 \\
\hline $\mathbf{2 0 0 6}$ & $299,398,484$ & $10,019,601$ & $1,198,245$ & 400,2 \\
\hline $\mathbf{2 0 0 7}$ & $301,621,157$ & $9,882,212$ & $1,100,472$ & 364,9 \\
\hline $\mathbf{2 0 0 8}$ & $304,059,724$ & $9,774,152$ & 959,059 & 315,4 \\
\hline $\mathbf{2 0 0 9}$ & $307,006,550$ & $9,337,060$ & 795,652 & 259,2 \\
\hline $\mathbf{2 0 1 0}$ & $309,330,219$ & $9,112,625$ & 739,565 & 239,1 \\
\hline $\mathbf{2 0 1 1}$ & $311,587,816$ & $9,052,743$ & 716,508 & 230 \\
\hline $\mathbf{2 0 1 2}$ & $313,914,040$ & $8,975,438$ & 721,053 & 229,7 \\
\hline
\end{tabular}

Source: Federal Burean of Investigation (FBI) Uniform Crime Reports, 2014 (mmn.ucrdatatool)

It is thus thought that by increasing the number of guardians, decreasing the suitability of targets or reducing the offender population, the crime rate should decline. A central implication of 
understanding offending in terms of a rational calculation means that the criminal justice system is capable of controlling crime, that aggressive law enforcement and severe punishment should deter offenders, and consequently, produce a notable reduction in criminal offending.

Offenders, particularly property offenders, may give some consideration to the chances of being caught; however, this does not appear to be the deciding factor in the decision to offend. It appears that, instead of thinking of the long-term negative consequences, offenders focus primarily on the immediate benefits associated with the offence. This suggests that offenders may not be as rationally motivated or calculating as it is often assumed.

\section{5-Discussion}

Since, the routine activity approach asserts that crime may be most common where three elements come together in time and space: motivated offenders, suitable targets, and absence of capable guardians (Cohen and Felson 1979), in this part, it will be given some explanations at what level the routine activity theory fits into property crimes. Also, these explanations include some details and examples to show how the routine activity theory fits to the property crimes, specifically, to burglary and auto vehicle theft.

Prior tests of routine activity theory have mostly found significant desirable effects of guardianship on crime (Hollis-Peel et al. 2011:12). Some examples can be checked about the importance of the guardianship in the houses during the day time. For example, Walker and Dagger (1993) state the number of individuals in a residence is a vital factor of threat in terms of being a victim of burglary. In addition, houses in which married couples live have less possibility of being victimized than other types of families (Phillips 1995). Yet, single parent families are in the danger group according to Lindsay and McGillis (1986) because those people tend to be single renters and frequently leave their houses unattended for long periods. After this information, when we turn back to routine activity theory, we can see the same viewpoint, because, according to the founders of the theory, the number of children in the family is a potential household guardianship. The more children in the home, the more likely one of them will be home. The longer the family has lived in the home, the more likely they have close ties with their neighbors who would recognize strange occurrences. Finally, it is seen that if some guardianship is available in the home then it is not a suitable target for burglars. In this situation, there is a likely offender, and target but the third element, "absence of guardianship," is not present. Consequently, the crime picture cannot be drawn.

One other issue in routine activity theory is "suitable targets" that mean potential targets are attractive and profitable to the burglars. For example, several studies revealed that residences situated on a corner are more susceptible to burglary than those on the middle of a block (Cromwell, Olson, and Avary 1991). Corner residences are reasonable places for burglars to knock on the door and ask for any address. It is a common tactic of burglars to find out whether anybody is at home. So, a residence in the middle of a building block is less noticeable and as a result less prone to burglary. In this example, as it is seen, the targets are selected by their features. Namely, while burglars decide to break into a house they assess the target's features before and then if it seems to be logical and easy to go in they conduct their action; otherwise they don't.

Nowadays the buildings which are mentoring with security guards are more referred because of crime fear. In RAT approach it is more convenient to choose this option. Just around everywhere motivated offenders looks for offense and in micro level a person or a high-valued material which can be saved in safety areas might break away being 'suitable target'. Consequently, this example somewhat verifies the rule of the "suitable target" principle of routine activity theory that if the target is suitable then crime may be committed; otherwise it will not.

As discussed above, residences surrounded by a wooded area or playground are generally more vulnerable to burglary since they do not have neighbors who may watch that residence. Also, woods provide concealed access (Hakim 1995). When we scrutinize this case we can see that the places which are in the wooded areas are chosen by burglars because wooded areas are suitable 
Argun, U., \& Dağlar, M. (2016). Examination of Routine Activities Theory by the property crime. International Journal of Human Sciences, 13(1), 1188-1198. doi:10.14687/ijhs.v13i1.3665

targets for burglars in terms of lack of guardianship and suitability of target due to easy hiding characteristics. Conversely, neighborhoods with high numbers of multi-family housing, especially high-rise apartments, had higher population density and these neighborhoods have tended to have much less burglary than neighborhoods that were more spread out. High-rise apartments provide some protection from potential offenders due to high guardianship numbers because of high population density. On the other hand multi-family housing and high apartments are not suitable targets like the ones in the wooded areas in terms of concealing access.

As indicated in a study (Wilcox et al. 2007), at the individual level, target hardening, place management and surveillance were related more negatively to burglary rates when neighborhoodlevel target hardening, natural surveillance, and informal social control increased. Moreover, the guardianship experiments such as in USA, Canada, Netherland and etc. can make to criminological knowledge is clarifying the causal mechanisms underlying the relationship between guardianship and crime (Hollis-Peel et al. 2011:27-35). Guardianship had a significant effect on decreasing the level and rate of property crime.

It can be said that the rules of the routine activity theory are also applicable to auto vehicle theft crimes. Routine activities theory (Felson 1994) suggests that unattended vehicles should create hot spots of vehicle crime. In this concern, Clarke and Harris (1992) state that the occurrence of auto theft in public is not a surprise when one thinks about its targets as generally accessible and available. They offer a variety of strong temptations to thieves, they are afforded little guardianship by their owners, and they seem relatively easy to enter and steal. Routine activity theory states that crimes will take place when a motivated offender encounters an opportunity to commit a crime. A chance for auto theft cannot exist in the place of a desirable vehicle if the owner is in the car. However, a few minutes later, the owners may be in their business or asleep at night, making the car an excellent target of vehicle theft. Yet, if the car was parked in an attended lot or one equipped with surveillance cameras, it would not be a fine target for theft.

On the other hand, the rise in recorded crime statistics is an issue which is hotly debated in all societies. Turkey's recorded crime figures which was raising in last decades shows that there has not been a significant rise in crimes against the person, but only in crimes against property. Some studies (Bahar and Fert 2008; Sargin and Temurcin 2011) shows that it is a problematic in Turkey that to what extent is it possible to reduce crimes against property by purely physical means such as increased security? There are different answers to that question depending on one's point of view, and to effectively reduce crimes against property factors which play a part in the execution of these crimes must be examined.

\section{6-Conclusion}

Routine activity approach suggests that deviant behavior occurs in the presence of three things that are a suitable target, lack of a suitable guardian, and a motivated offender. So, a crime happens when these three elements comes together at any place at any time. Namely, if all three elements are present somewhere, then the chances for crime increase, and when one of these elements is absent then chances for crime decrease.

Both target accessibility and guardianship are important things in the routine activity approach to crime. So, this idea is best articulated in the routine activity approach to property crime. If we scrutinize the routine activity theory in terms of property crime, the mentioned specific examples show us that especially burglary and motor vehicle theft crimes fit into the theory. Consequently, when we consider the routine activity theory, an effective measure for preventing burglary and motor vehicle theft can be making targets difficult to criminals that called "target hardening." Target hardening makes crime more difficult for offenders to carry out it on specific targets. The use of locked doors, windows, alarm systems, and watch dogs are all examples of target hardening which aims to prevent becoming a victim of crime. The combination of target hardening and a suitable guardian is a very effective way to prevent being a victim of burglary and motor vehicle theft. 
It seems like property crimes made up an overwhelming majority of all crimes and generally involve low crime rates of clearance. Homes, garages, cars and businesses are all susceptible to the attentions of thieves. Additionally, as indicated before, the victims of property crimes may suffer from big economic loss depending on what was stolen from their property and negative psychological effects for a long time. So, it can be said that policies which are based on the routine activities theory are a logical step of crime prevention.

From this stand point, Routine Activity Theory (RAT) may be used as a useful tool by crime reduction/prevention practitioners to evaluate crime problems and also take routine precautions and measures that reduce crime opportunities in people's daily activities.

\section{References}

Bahar, H. I. and Fert, I. (2008). The Debate over Recent Recorded Crime Rate in Turkey", International Journal of Social Inquiry, Vol.1, No: 1:89-104.

Brunet, J. R. (2002). "Discouragement of Crime Through Civil Remedies: An Application of a Reformulated Routine Activities Theory", Western Criminology Review 4 (1): 68-79.

Buikhuisen, W., Bontekoe, E. H. M., Plas-Korenhoff, C., \& Van Buuren, S. (1984). Characteristics of criminals: The privileged offender. International Journal of Law and Psychiatry, 7(3), 301-313, Retrieved March 25, (http://www.stefvanbuuren.nl/publications/Characteristics $\% 20$ \%20Int \%20J\%20Law\%20Psych\%201984.pdf)

Clarke, Ronald V. (1997). Situational Crime Prevention: Successful Case Studies. Second ed. Guilderland, NY: Harrow and Heston.

Clarke, R.V. and Cornish, D. B. (1985). Modeling Offenders' Decisions: A Framework for Research and Policy. In: M. Tonry and N. Morris (eds.) Crime and Justice, Volume Number: 6.

Clarke, R.V., and P.M. Harris. (1992). Auto Theft and Its Prevention. In: M. Tonry and N. Morris (eds.) Crime and Justice: A Review of Research, Vol. 16. Chicago: University of Chicago Press.

Cohen, Lawrence and Felson, M. (1979). Social change and crime rate trends: A routine activity approach. American Sociological Review 44, 588-608.

Cornish, D., and R. Clarke. (1987). Understanding crime displacement: An application of rational choice theory. Criminology, 25(4), 933-947.

Cromwell, P., Olson, J. and Avary, D. (1991). Breaking and Entering: An Ethnographic Analysis of Burglary. Newbury Park, CA: Sage.

Degarmo, M. (2011). Understanding the Comparisons of Routine Activities and Contagious Distributions of Victimization: Forming a Mixed Model of Confluence and Transmission", International Journal of Criminology and Sociological Theory, Vol. 4, No. 1, 584-603.

Dolu, Osman. (2009a). Crime as a Function of Opportunity: Situational Determinants of Crime, Crime Opportunities and Routine Activities Theory, Turkish Journal of Police Studies, 11 (2): 130 .

Dolu, Osman. (2009b). Crime as a Rational Choice: An Evaluation of the Capacity of Classical School of Criminology in Explaining and Preventing Crime. Turkish Journal of Police Studies Vol: 11 (4): 89-120.

Dolu, Osman. (2010). Suc Teorileri: Teori, Araștırma ve Uygulamada Kriminoloji, Ankara, Seçkin Yay.

Federal Bureau of Investigation (FBI), (2003). Crime in the United States, 2002. Washington, DC: United States Government Printing Office. 
Argun, U., \& Dağlar, M. (2016). Examination of Routine Activities Theory by the property crime. International Journal of Human Sciences, 13(1), 1188-1198. doi:10.14687/ijhs.v13i1.3665

Federal Bureau of Investigation (FBI), (2004). Crime in the United States, 2003. Washington, DC: United States Government Printing Office.

Federal Bureau of Investigation (FBI). (2012). Uniform Crime Reports as prepared by the National Archive of Criminal Justice Data, US Department of Justice, Retrieved January 21, 2014, (http://www.ucrdatatool.gov/Search/Crime/State/RunCrimeStatebyState.cfm)

Felson, M. (1994). Crime and Everyday Life. Thousand Oaks, CA: Pine Forge Press. Hakim, S. (1995). Securing Suburban Homes: The Greenwich Case. Bethesda, Maryland: Alarm Industry Research and Education Foundation.

Hollis-Peel, M. E., Reynald, D. M., Bavel, M., Elffers, H. and Welsh, B. C. (2011). Guardianship for Crime Prevention: A Critical Review of the Literature. In: Crime, Law and Social Change 56, 1, pp. 53-70.

Lindsay, B. and McGillis D. (1986). Citywide Community Crime Prevention: An Assessment of the Seattle Program. in Dennis P. Rosenbaum (ed.). Community Crime Prevention: Does it Work? Los Angeles: Sage Publications.

NSW Attorney General. (2011). Routine Activity Theory; Crime Prevention. Retrieved November 13, 2015 from New South Whales Attorney General and Justice: (http://www.crimeprevention.nsw.gov.au/agdbasev7wr/ assets/cpd/m66000112/routinea ctivityfactsheet nov2011.pdf.)

Pease, K. (1992). Preventing Burglary on a British Public Housing Estate. In Situational Crime Prevention: Successful Case Studies (First Edition), edited by Ronald V. Clarke. Albany, NY: Harrow and Heston.

Phillips, T. (1995). State Differences in Burglary Victimization in Australia: An Exploratory Analysis. In Crime Victims Surveys in Australia: Conference Proceedings Brisbane: Criminal Justice Commission.

Poyner, B. (1997). Situational Crime Prevention in Two Parking Facilities. In Situational Crime Prevention: Successful Case Studies (Second Edition), ed Ronald V. Clarke. Albany, NY: Harrow and Heston.

Prenzler, T. and Townsley, M. (1998). The Prospects for Burglary Prevention in Australia, Current Issues in Criminal Justice, Vol:9, No:3, pp.294-311.

Sargın S. ve Temurçin, K. (2011). Türkiye’nin Suç Coğrafyası. Ankara: Polis Akademisi Yayınları.

Sherman, L.W., P.R. Gartin and Buerger, M. E. (1989). Hot Spots of Predatory Crime: Routine Activities and Criminology of Place, Criminology, (4), 1, pp. 27-56

Taylor, I. (1995). Private Homes and Public Others. British Journal of Criminology, 35/2:263-85.

U.S. Department of Justice. (2012). Property Crime, Bureau of Justice Statistics. Retrived January 23, 2014 (http://www.bjs.gov/index.cfm?ty=tp\&tid=32\#terms_def)

Walker, J. and Dagger, D. (1993). Crime in Australia. Canberra: Australian Institute of Criminology.

Wilcox, Pamela, Kenneth C. Land, and Scott Hunt. (2003). Criminal Circumstance: A Dynamic Multicontextual Criminal Opportunity Theory. New York: Walter de Gruyter.

Wilcox, P., Madensen, T. D. and Tillyer, M. S.. (2007). Guardianship in Context: Implications for Burglary Victimization Risk \& Prevention. Criminology, 45 (4):771-803. 